\title{
IMMUNOHISTOCHEMICAL STUDY ON THE DEVELOPMENT OF GASTRIN CELLS IN THE STOMACH, DUODENUM AND PANCREAS OF THE RAT
}

\author{
Katsuko Kataoka', Junko Miura ${ }^{2}$, Yasuko Takeoka' and Noboru Yanaihara ${ }^{3}$ \\ 'Department of Anatomy, Hiroshima University School of Medicine, Hiroshima 734, ${ }^{2}$ Biwako-Yoikuin Hospital, \\ Otsu 520-21, and ${ }^{3}$ Laboratory of Bioorganic Chemistry, Shizuoka College of Pharmacy, Shizuoka 422, Japan
}

\begin{abstract}
With the use of anti-human G17 I serum (R-1301), antiserum R-1301 previously absorbed with pentagastrin (R-1301-G5), and anti-human G34[1-15] serum (R-2703), at least two subpopulations of gastrin-like immunoreactive cells were demonstrated in the pyloric mucosa of the adult rat. The majority of cells are reactive with all the antisera (typical gastrin-like immunoreactivity), but some cells react only with R-1301 (C-terminal immunoreactivity). A few cells of either subpopulation are present in the duodenum, but none in the pancreas of the adult rat. In the pyloric mucosa, typical gastrin-like as well as C-terminal immunoreactive cells first appear on day 20 of gestation, and gradually increase in number during postnatal development. In the duodenum and pancreas, Cterminal and typical gastrin-like immunoreactive cells first appear on day 18 and day 20 of gestation, respectively. In the duodenum, few remain during development. In the pancreas, typical gastrin-like and C-terminal immunoreactive cells disappear on postnatal day 4 and day 7, respectively. Extrapyloric gastrin cells in perinatal rats are mostly only Cterminal immunoreactive.
\end{abstract}

Gastrin is one of the most important and wellknown gut hormones, and many studies have been made on gastrin-producing cells $(1,5)$. Ontogenetic studies on gastrin cells have been mainly performed in the rat using antisera reactive with C-terminal region of gastrin $(9,11,13)$. In recent years, much interest has been directed toward molecular heterogeneity of gastrin due to enzymatic modifications of the precursor protein $(4,15)$. The presence of TG (terminal gastrin) cells, which are immunohistochemically reactive with $\mathrm{C}$-terminal antisera but unreactive with other region-specific antisera of gastrin or cholecystokinin (CCK), has been reported (10, 12). Iwanaga et al. (7) performed an immunohistochemical study on pyloric gastrin cells of various mammals including rats using two different region-specific antisera and found two subpopulations in anti-G17 serum-positive cells. The major subpopulation was reactive with anti-
G34[1-15] serum, and the minor subpopulation was not or only weakly reactive with antiG34[1-15] serum. These findings stimulated our immunohistochemical study on ontogenesis of gastrin cells using different region-specific antisera.

\section{MATERIALS AND METHODS}

\section{Tissue Preparation}

Wistar rat fetuses (days 16, 18 and 20 of gestation, vaginal plug=day 0 ), young animals (postnatal days $0,2,4,7,14,21,28$ and 42) and adults (postnatal day 56) were used in this study. The stomach, the proximal part of the duodenum and the pancreas were removed and fixed overnight in modified Bouin's solution (saturated picric acid solution: formalin $=3: 1$ ). Paraffin sections (1.5-3 $\mu \mathrm{m}$ in thickness) were cut and used for immunohistochemical study. 


\section{Immunohistochemistry}

Anti-human G17 I serum (R-1301), antiserum R-1301 previously absorbed with pentagastrin (R-1301-G5) and anti-human G34[1-15] serum (R-2703) were used for immunohistochemical studies. Antiserum R-1301 was produced in a rabbit immunized with synthetic Gly-Lys[GIn']-human G17 I (non-sulfated form) and was immunochemically specific for 6-12 sequence of human G17 I (17). Antiserum R-2703, specific for 1-7 sequence of human G34, was obtained from a rabbit immunized with synthetic human G34[1-15] (19).

Immunohistochemistry was performed using the peroxidase-antiperoxidase (PAP) method (16). Deparaffinized sections were incubated for $90 \mathrm{~min}$ at $37^{\circ} \mathrm{C}$ with the primary antiserum, i.e. with any one of R-1301, R-1301-G5 and R-2703, at a dilution of 1:900 in phosphate-buffered saline. Sections were then treated with swine anti-rabbit $\mathrm{IgG}$ and peroxidase-rabbit anti-peroxidase complex (DAKO immunoglobulins $\mathrm{a} / \mathrm{s})$, successively. The sections were incubated with 3,3'-diaminobenzidine tetrahydrochloride and $\mathrm{H}_{2} \mathrm{O}_{2}$ to visualize the complex (6) and then stained with Mayer's hematoxylin.

\section{Controls for Immunohistochemical Specificity}

Immunohistochemical specificity was tested by using the following sera instead of the primary antisera: 1) antiserum R-1301 previously absorbed with synthetic human G34[1-15], synthetic human G17 I or synthetic pentagastrin, 2) antiserum R-2703 absorbed with either synthetic human G34[1-15] or synthetic human G17 I, and 3) non-immune rabbit serum. Non-absorbed and absorbed antisera were applied to $1.5 \mu \mathrm{m}$-thick serial sections, respectively.

\section{RESULTS}

\section{In Adult Rats (Figs. 1-3 and 6e)}

In the adult rat, gastrin-like immunoreactive cells were mainly demonstrated in the deeper region of the pyloric mucosa using any primary antiserum, R-1301, R-1301-G5 or R-2703 (Fig. $6 \mathrm{e})$. They represented the typical form of an open-type basal-granulated cell. In the duodenum, a small number of immunostained cells could be seen in the villous or crypt epithelium by any antiserum. No immunoreactive cells were found in the pancreas of the adult. The results of immunohistochemical specificity tests are summarized in Table 1. In addition, careful examina-
Table 1 Immunohistochemical Specificity Tested in Adult Rats

\begin{tabular}{lll}
\hline \multicolumn{1}{c}{ Antisera } & $\begin{array}{c}\text { Peptides used for } \\
\text { absorption }\end{array}$ & \\
\hline R-1301 & G34[1-15] & + \\
R-1301 & G17 I & - \\
R-1301 & pentagastrin & + (majority) \\
R-1301 & & \pm (some) \\
& & - (some) \\
& & + \\
R-2703 & G34[1-15] & - \\
R-2703 & G17 I & + \\
R-2703 & & - \\
Non-immune & & \\
rabbit serum & & \\
\hline
\end{tabular}

+ : intensely stained, \pm : very weakly stained, - : not stained

tion was made on the serial sections stained with three different combinations of the primary antisera; R-1301 and R-1301-G5, R-1301 and R-2703, and R-2703 and R-1301-G5, respectively (Figs. 13). The majority of immunoreactive cells were consistent with any combination of the antisera. However, some discrepancies were found in a minority of cells. When R-1301- and R-1301-G5immunostained cells were compared, a few cells stained by R-1301 were not stained by R-1301-G5 (Fig. 1). These cells were often small in their size. In addition, some R-1301-reactive cells exhibited only weak reaction with R-1301-G5. When the combination, R-1301 and R-2703, was compared, immunostained cells by the former appeared to be more numerous than those by the latter. This discrepancy is largely attributable to the fact that some cells exhibit intense reaction with R-1301 but only weak reaction with R-2703, and moreover, a few cells intensely reactive with R-1301 were completely nonreactive with R-2703 (Fig. 2). R-2703- and R-1301-G5-immunostained cells were more consistent than the other two combinations. However, occasional discrepancy was observed in the intensity of immunostaining between the two antisera: a few cells which intensely reacted with R-2703 showed only a slight reaction with R-1301-G5, or vice versa (Fig. 3).

From these data, gastrin-like immunoreactive cells in the adult rat can be classified into two subpopulations, even when the positive or negative immunostaining with each antiserum is taken into account and the discrepancy in the intensity of staining is not taken into consideration. The majority of gastrin-like immunoreactive cells is consistently reactive with all three antisera, R- 

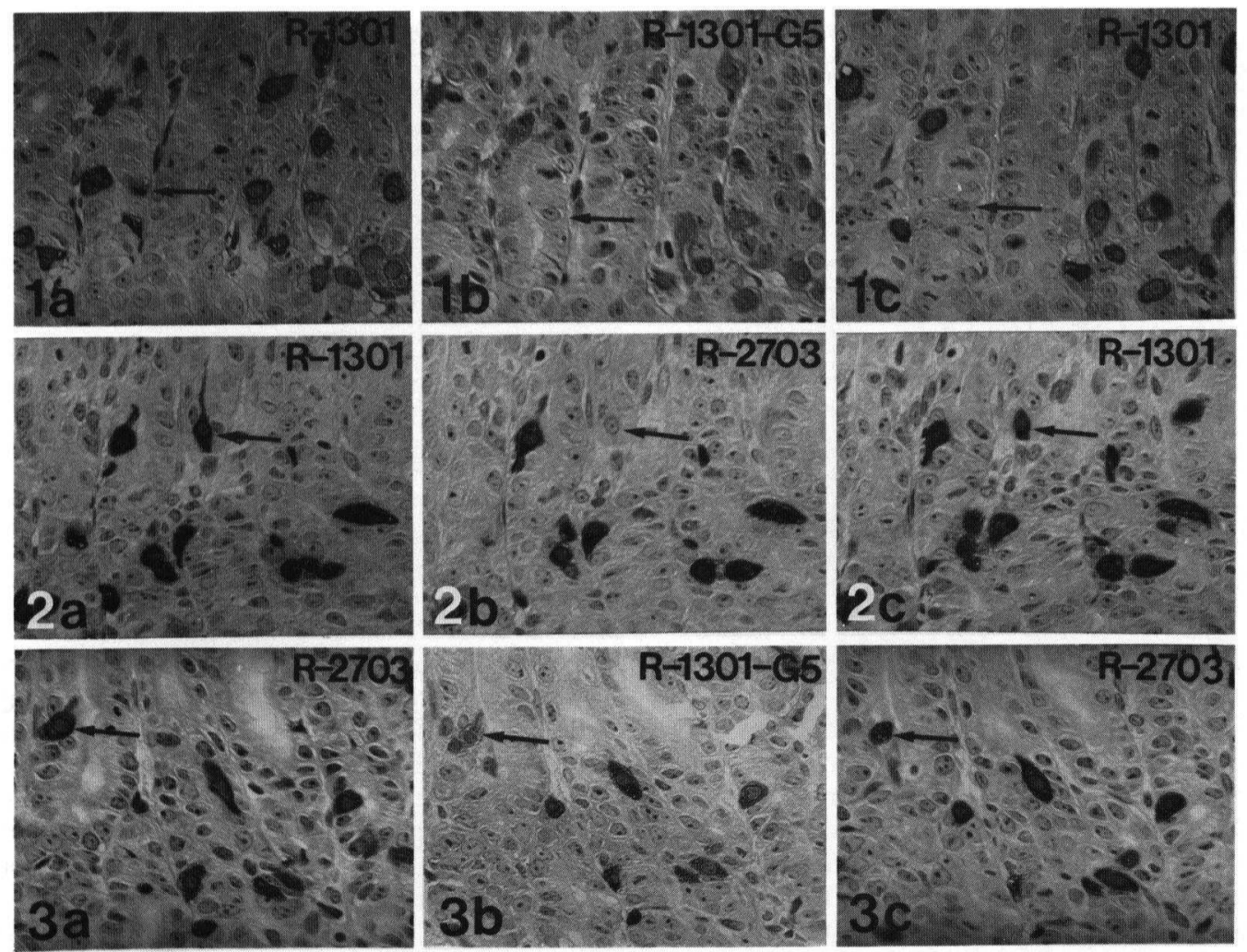

Figs. 1-3 Pyloric mucosa of the adult rat stained with antiserum R-1301, R-1301-G5 or R-2703. a, b and c are serial sections. Most immunoreactive cells are consistent between any pair of the antisera. However, cells indicated by arrows are intensely stained in a and c, but not stained in $1 \mathrm{~b}$ and $2 \mathrm{~b}$ and only faintly stained in $3 \mathrm{~b} . \times 300$

1301, R-1301-G5 and R-2703. These cells are tentatively called typical gastrin-like immunoreactive cells in this report. A few gastrin-like immunoreactive cells are reactive with R-1301 but unreactive with R-1301-G5 and R-2703. These cells are tentatively called gastrin C-terminal immunoreactive cells.

\section{In Developing Rats (Figs. 4-6)}

The appearance of gastrin-like immunoreactive cells in developing rats is summarized in Table 2. The two subpopulations of the cells, typical gastrin-like immunoreactive cells and gastrin $\mathrm{C}$ terminal immunoreactive cells, could be distinguished in developing rats as well as in adults. In the pyloric mucosa, a few gastrin-like immunoreactive cells were first detected on day 20 of gestation using either R-1301, R-1301-G5 or R-2703 as the primary antiserum (Fig. 5, a and b). They belonged to either subpopulation, typical gastrinlike or C-terminal immunoreactive cells. They gradually increased in number during postnatal development (Fig. 6). The proportion of typical gastrin-like immunoreactive cells to the total

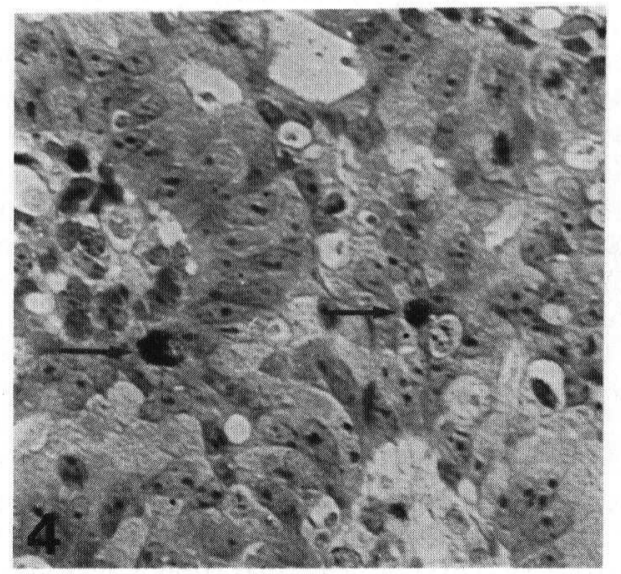

Fig. 4 R-1301-immunoreactive cells (arrows) in the duodenum on day 18 of gestation. $\times 600$ 
Table 2 Presence of Immunoreactive Cells during Development

\begin{tabular}{|c|c|c|c|c|c|c|}
\hline & \multicolumn{2}{|c|}{ Pyloric antrum } & \multicolumn{2}{|c|}{ Duodenum } & \multicolumn{2}{|c|}{ Pancreas } \\
\hline & R-1301 & $\mathrm{R}-2703$ & $\mathrm{R}-1301$ & $\mathrm{R}-2703$ & R-1301 & R-2703 \\
\hline \multicolumn{7}{|l|}{ Fetal } \\
\hline Day 16 & - & - & - & - & - & - \\
\hline Day 18 & - & - & + & - & + & - \\
\hline Day 20 & + & + & + & + & + & + \\
\hline \multicolumn{7}{|l|}{ Postnatal } \\
\hline Day 2 & + & + & + & + & + & + \\
\hline Day 4 & + & + & + & + & + & - \\
\hline Day 7 & + & + & + & + & - & - \\
\hline \multicolumn{7}{|l|}{ Adult } \\
\hline Day 56 & $\begin{array}{c}+ \\
\text { large } \\
\text { number }\end{array}$ & $\begin{array}{c}+ \\
\text { large } \\
\text { number }\end{array}$ & + & + & - & - \\
\hline
\end{tabular}

Presence of R-1301-G5-immunoreactive cells coincides with that of R-2703immunoreactive cells. +: present, -: absent

gastrin-like immunoreactive cells increased simultaneously.

The oxyntic mucosa of the stomach did not show gastrin-like immunoreactivity in any developing period except for the transitional zone between the oxyntic and pyloric mucosa.

In the duodenal mucosa, C-terminal immunoreactive cells were first demonstrated on day 18 of gestation (Fig. 4). Typical gastrin-like immunoreactive cells appeared 2 days later (Fig. 5d). R1301-immunoreactive cells in the duodenum, the majority of which were only C-terminal immunoreactive, somewhat increased in number during the perinatal period and exceeded the number of those in the pyloric antrum. After the first postnatal week, the pyloric antrum became the major site of gastrin cells.

In the pancreas, C-terminal immunoreactive cells first appeared on day 18 of gestation. They were most numerous from day 20 of gestation to postnatal day 2 , and were mainly located in the periphery of the islet, where ductules associated with the islet were often seen (Fig. 5e). They decreased in number on postnatal day 4 and disappeared on day 7. Typical gastrin-like immunoreactive cells were occasionally found among C-terminal immunoreactive cells from day 20 of gestation to postnatal day 2 (Fig. 5, f and g).

\section{DISCUSSION}

Using anti-human G17 I serum (R-1301), antiserum R-1301 previously absorbed with pentagastrin (R-1301-G5) and anti-human G34[1-15] serum (R-2703), at least two subpopulations of gastrin-like immunoreactive cells were demonstrated in this study. The major subpopulation reactive with all antisera is called typical gastrinlike immunoreactive cells, whereas the minor subpopulation reactive only with R-1301 is regarded as gastrin $\mathrm{C}$-terminal immunoreactive cells. Since G34 and G17 are produced by the successive tryptic cleavage of a larger precursor molecule $(3,4,14,15)$, it is evident that the major subpopulation is reactive with all antisera.

The nature of the minor subpopulation, gastrin C-terminal immunoreactive cells, is obscure. Immunochemically, antiserum R-1301 is specific for 6-12 sequence of G17 I (non-sulfated form), and does not cross-react with sulfated form (G17 II) (17). Antiserum R-2703 is specific for 1-7 sequence of G34 (19). Furthermore, G34 Nterminus, pGlu-, is so crucial to the immunoreactivity with R-2703 that the precursor peptide accompanying N-terminal extension, pGlu- to -Gln-, might greatly reduce the immunoreactivity with R-2703 (18). These immunochemical characteristics of the antisera would offer the first possible explanation for the C-terminal immunoreactive cell that the cell actually contains gastrin-related molecules, but certain conformational changes of the molecules (extension or modification of $\mathrm{G} 34 \mathrm{~N}$-terminus, tyrosine- $\mathrm{O}$-sulfation, etc.) make them unreactive with R-2703 and R-1301-G5. A similar speculation was also made by Iwanaga et al. (7), who immunohistochemically studied pyloric gastrin cells of various mammals using anti-human G34[1-15] serum, R-2702 (specific for 1-5 sequence of G34), and antiserum R-1301 and found the presence of cells strongly reactive with R-1301 but only weakly reactive or unreactive with $\mathrm{R}-2702$.

Pancreatic gastrin in perinatal rats is particularly interesting in reviewing the nature of $\mathrm{C}$ - 

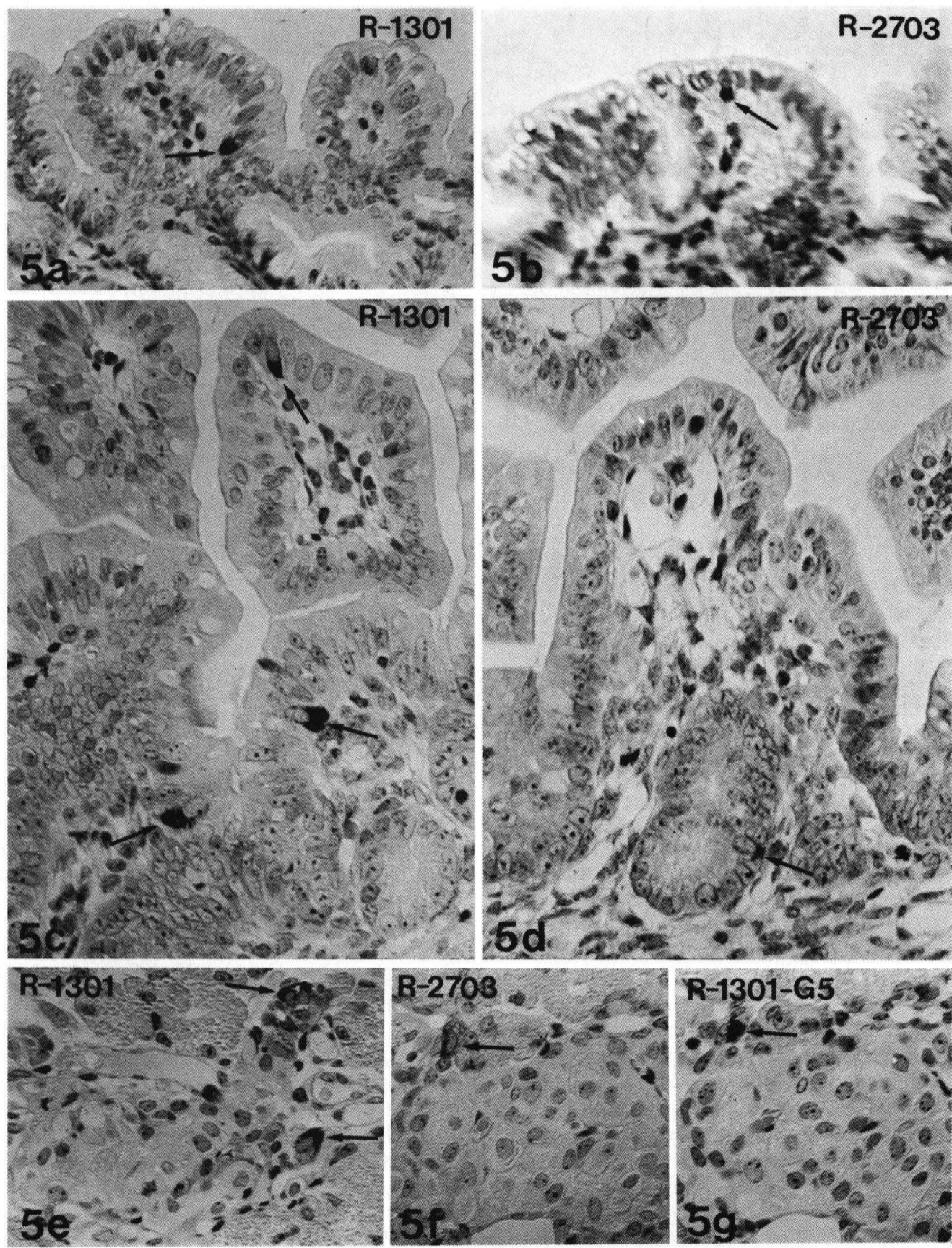

Fig. 5 Immunoreactive cells (arrows) in the pyloric antrum (a, b), duodenum (c, d) and pancreas (e-g) on day 20 of gestation. $f$ and $g$ are serial sections, and show an identical cell stained with R-2703 or R-1301-G5. $\times 400$ 


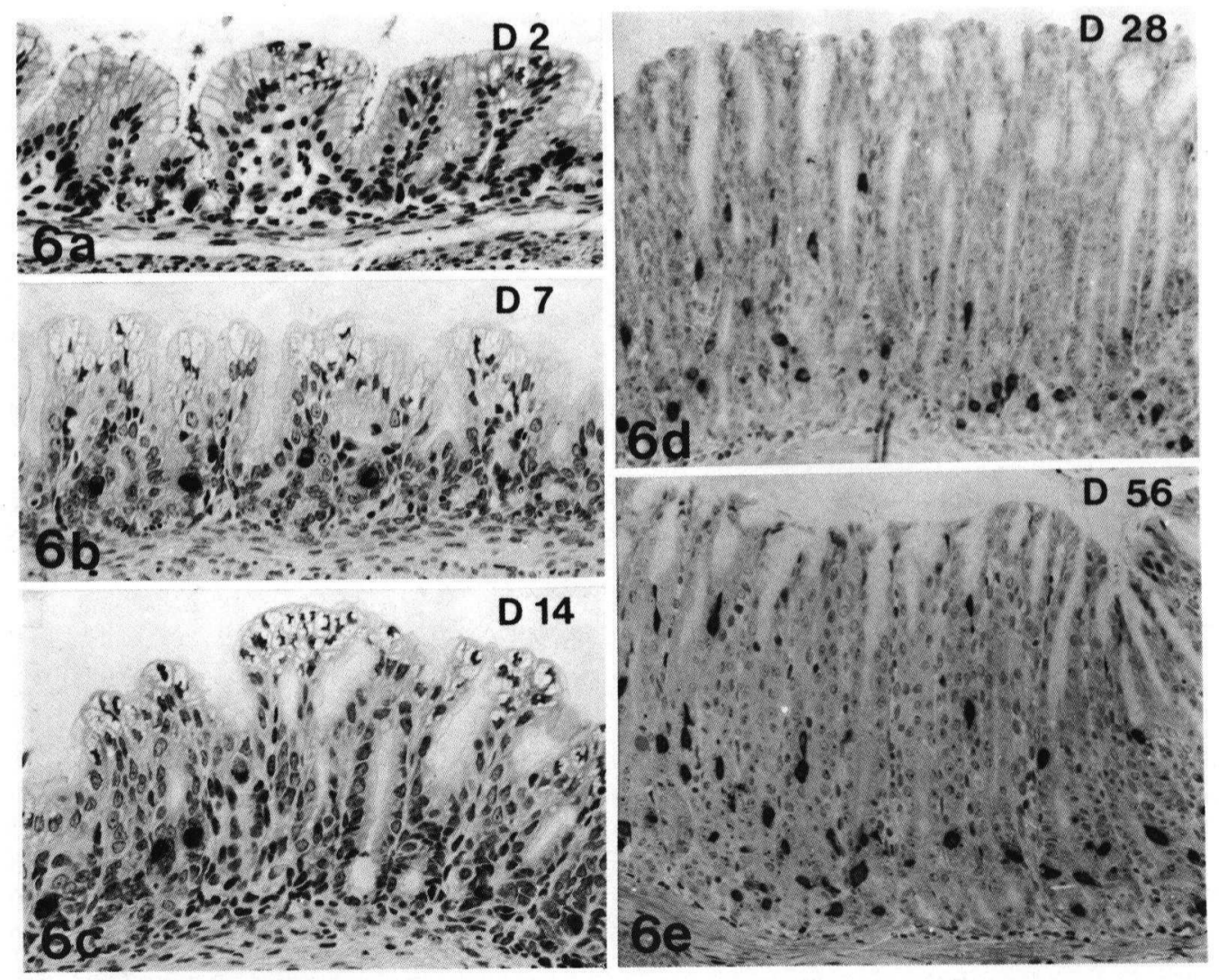

Fig. 6 R-1301-immunoreactive cells in the pyloric mucosa on postnatal days 2 (a), 7 (b), 14 (c), 28 (d) and 56 (e). a-c. $\times 350$; $d$ and e, $\times 150$

terminal immunoreactive cells. The main component of pancreatic gastrin is G17 (component III) $(2,13)$ and completely tyrosine- $O$-sulfated (2), although components I, II (G34) and IV (G15, G14) can be found in smaller amounts (13). In the present study, an overwhelming majority of gastrin-like immunoreactive cells was only C-terminal immunoreactive. The failure of immunostaining with antiserum R-1301-G5 seems reasonable, since this antiserum does not cross-react with the sulfated form of G17 (17). The failure of immunostaining with antiserum R-2703 further suggests that these cells contain no, if any, G34 or G34 N-terminal peptide in the form immunohistochemically detectable with this antiserum. The possible cause of this is that 1) G34 is not produced in these cells, 2) G34 Nterminus is rapidly modified or degraded, or 3 ) the unreactiveness is related to the microheterogeneity of gastrin, i.e. the presence of at least four different forms in each gastrin component I-IV
(15). Further studies on pancreatic gastrin may contribute in elucidating post-translational processing of gastrin.

The second possible explanation for the Cterminal immunoreactive cell is that it contains no or little gastrin-related molecules other than C-terminal portion such as CCK cells and TG cells. TG cells contain $\mathrm{C}$-terminal tetrapeptide amide of gastrin and are immunohistochemically demonstrated by antisera specific for C-terminus but not by antisera raised against other gastrinor CCK-specific sequences $(10,12)$. However, the presence of TG cells is still controversial (4). Finally, it is also possible that C-terminal immunoreactive cells may not represent a single cell type. Whatever the nature of the C-terminal immunoreactive cell, it might secrete biologically active $\mathrm{C}$-terminal peptide.

The present results on the development of rat gastrin cells coincide with the results of Larsson et al. $(9,11,13)$ as far as total gastrin-like immu- 
noreactive cells are concerned. They appear earlier in the duodenum and pancreas (on day 18 of gestation) than in the pyloric antrum (on day 20 of gestation), and these extrapyloric gastrin cells are more numerous than pyloric gastrin cells during the perinatal period. In addition, the present study revealed most of these extrapyloric gastrin cells to be only C-terminal immunoreactive. A small number of typical gastrin-like immunoreactive cells first appear on day 20 of gestation in the pyloric antrum, duodenum and pancreas, and they gradually increase in number in the pyloric antrum during postnatal development. In the mouse pyloroduodenal mucosa, the appearance of typical gastrin-like immunoreactive cells on postnatal day 0 is also preceded by the appearance of C-terminal immunoreactive cells on day 16 of gestation (8). These suggest that a peptide or peptides secreted by C-terminal immunoreactive cells play an important role in development and/or functional regulation of the gastric mucosa, pancreas, etc. during the perinatal period.

This study was supported by a Grant-in-Aid for Cancer Research and a Grant-in-Aid for Scientific Research from the Ministry of Education, Science and Culture, Japan. The authors are grateful to Mr Kenji Joji, Translation Section, Radiation Effects Research Foundation, Hiroshima, Japan, for his kind assistance in preparing the manuscript.

\section{Received for publication 26 December 1984}

\section{REFERENCES}

1. Bloom S. R. (ed) (1978) Gut Hormones, Churchill Livingstone, Edinburgh/London/New York

2. Brand S. J., ANDERsen B. N. and Rehfeld J. F. (1984) Complete tyrosine- $O$-sulphation of gastrin in neonatal rat pancreas. Nature 309, 456-458

3. Dockray G. J., Vaillant C. and Hopkins C. R. (1978) Biosynthetic relationships of big and little gastrins. Nature 273, 770-772

4. Dockray G. J., Vaillant C. and Hutchison J. B. (1981) Immunochemical characterization of peptides in endocrine cells and nerves with particular reference to gastrin and cholecystokinin. In Cellular Basis of Chemical Messengers in the Digestive System (ed. Grossman M. I., Brazier M. A. B. and Lechago J.) Academic Press, New York, pp. 215230

5. Fujita T. and Kobayashi S. (1977) Structure and function of gut endocrine cells. Int. Rev. Cytol. Suppl. 6, 187-233

6. Graham R. C. and Karnovsky M. J. (1966) The early stages of absorption of injected horseradish peroxidase in the proximal tubules of mouse kidney: Ultrastructural cytochemistry by a new technique. J. Histochem. Cytochem. 14, 291-302

7. Iwanaga T., Kusumoto Y., Fujita T., Yanaihara C., Mochizuki T. and Yanaihara N. (1980) Immunocytochemical localization of the different gastrin forms in the pyloric antrum. Biomedical Res. 1, 316-320

8. Kataoka K., Miura J., Takeoka Y., Kusumoto Y. and Yanaihara N. (1985) Ontogenesis of gastrin cells in the pyloric antrum and duodenum of the mouse. Cell Tissue Res. (in press)

9. LARSSON L.-I. (1977) Ontogeny of peptide-producing nerves and endocrine cells of the gastro-duodeno-pancreatic region. Histochemistry 54, 133142

10. Larsson L.-I., Capella C., Jørgensen L. M. and SolCIA E. (1981) Ultrastructural identification of TG cells in man and monkey. In Cellular Basis of Chemical Messengers in the Digestive System (ed. Grossman M. I., Brazier M. A. B. and LechaGo J.) Academic Press, New York, pp. 133-138

11. Larsson L.-I., Håkanson R., Rehfeld J. F., STADIL F. and SundLER F. (1974) Occurrence and neonatal development of gastrin immunoreactivity in the digestive tract of the rat. Cell Tissue Res. 149, 275-281

12. Larsson L.-I. and Rehfeld J. F. (1979) A peptide resembling COOH-terminal tetrapeptide amide of gastrin from a new gastrointestinal endocrine cell type. Nature 277, 575-578

13. Larsson L.-I., Rehfeld J. F., Sundler F. and HÅKANSON R. (1976) Pancreatic gastrin in foetal and neonatal rats. Nature 262, 609-610

14. Noyes B. E., Mevarech M., Stein R. and AgarWAL K. L. (1979) Detection and partial sequence analysis of gastrin mRNA by using an oligodeoxynucleotide probe. Proc. Natl. Acad. Sci. USA 76, 1770-1774

15. RehFeld J. F. (1981) Four basic characteristics of the gastrin-cholecystokinin system. Amer. J. Physiol. 240, G255-G266

16. Sternberger L. A. (1974) Immunohistochemistry, Prentice-Hall, Englewood Cliffs, NJ

17. Yanaihara C., Yanaihara N., Shimizu F., Sato H., Uehata S. and Imagawa K. (1980) A new type of gastrin derivative and its use for production of central region-specific antigastrin sera. Biomedical Res. 1, 242-247

18. Yanaihara N. (1980) Immunochemical application of synthetic peptides to studies on the prohormone-hormone system. Biomedical Res. 1, 105116

19. Yanaihara N., Yanaihara C., Ozaki J., Mochlzuki T., Shimizu F., Mihara S., Nagai K., Sato H. and SaKagami M. (1979) Human big gastrin Nterminal fragment immunoreactivity. In Gut Peptides (ed. MiYoshi A.) Kodansha, Tokyo, pp. 26-33 